\title{
Universiteit
}

Leiden

The Netherlands

\section{Modelling as a Tool for Cross-border Analysis of the Position of Insolvency Office Holders}

Santen, B.P.A.; Adriaanse, J.A.A.; Wuisman, I.S.

\section{Citation}

Santen, B. P. A., Adriaanse, J. A. A., \& Wuisman, I. S. (2016). Modelling as a Tool for Cross-border Analysis of the Position of Insolvency Office Holders. International Insolvency Review, 25(3), 167-178.

doi:10.1002/iir.1259

Version: Publisher's Version

License: $\quad$ Leiden University Non-exclusive license

Downloaded from: $\quad$ https://hdl.handle.net/1887/44683

Note: To cite this publication please use the final published version (if applicable). 


\title{
Modelling as a Tool for Cross-border Analysis of the Position of Insolvency Office Holders
}

\author{
Bernard Santen $^{1 *}$, Jan Adriaanse ${ }^{2}$ and Iris Wuisman ${ }^{3}$ \\ ${ }^{1}$ Until 1 November 2015 Senior Researcher, Department of Business Studies, Leiden Law School, Leiden, \\ The Netherlands \\ ${ }^{2}$ Professor of Turnaround management, Leiden Law School, Leiden, The Netherlands \\ ${ }^{3}$ Professor of Company Law, Leiden Law School, Leiden, The Netherlands
}

\begin{abstract}
This paper presents a framework and a model applied to make a cross-border analysis of the position of Insolvency Office Holders. Both the framework and the model were developed in the course of an assignment to design Principles and Best Practices for Insolvency Office Holders for INSOL Europe. The framework is developed by induction from a variety of sources of rules and regulations regarding Insolvency Office Holders, while the model subsequently has been derived by deduction from the framework. Finally, the paper shows how this method assisted in determining the issues to be covered by Principles and Best Practices. The authors argue that commencing international legal comparison with abstract reasoning and modelling may lessen the effect of researcher's academic or professional blind spots and cultural bias and has the potential to enhance the value of cross-border analysis in terms of coherence, consistency and completeness. Copyright (C) 2016 INSOL International and John Wiley \& Sons, Ltd.
\end{abstract}

\section{Introduction}

Early 2013 INSOL Europe ${ }^{1}$ commissioned a project to develop a Statement of Principles and Best Practices for Insolvency Office Holders ('IOHs') ${ }^{2}$ in Europe

\footnotetext{
*E-mail: bernard@santenonline.nl

1. The authors would like to express their gratitude to the INSOL Europe organisation for having commissioned the project to them. Their gratitude concerns as well a great number of INSOL Europe members and others who have been seated in the Review \& Advisory Group and the Academic Committee to the project for their continuous support and cooperation. See for the project reports: wrerw.tri-leiden.eu, button Insolvency Office Holders
}

Project and for the names of the people involved pages 3 and 5 of each of the reports.

2. The neutral concept of the Insolvency Office Holder to depict numerous different descriptions of approximately the same profession in various countries was coined by the EBRD 2007 study: EBRD Insolvency Office Holder Principles, EBRD Principles in Respect of the Qualifications, Appointment, Conduct, Supervision, and Regulation of Office Holders in Insolvency Cases, available on the EBRD website. 
('Statement') to the Leiden Law School ('LLS'). ${ }^{3}$ The project consisted of two studies on the position of the IOH ('INSOL Europe studies') and the final Statement. ${ }^{4}$ The Statement was presented to the members at INSOL Europe's annual conference in 2014. In this paper, we report our search for an academically sound method to design the Statement. ${ }^{5}$

This paper focuses on the role of modelling in the legal and comparative analysis of the position of IOHs. Searching for 'modelling in legal analysis' in Scholar Google displays approximately 170000 hits. ${ }^{6}$ The relevant ones relate to, for example, modelling legal information, ${ }^{7}$ modelling legal reasoning, ${ }^{8}$ modelling a court's hearing procedure ${ }^{9}$ and modelling judicial decision making, for example, by means of artificial intelligence. ${ }^{10}$ These subjects are not helpful because we attempt to model the position of an IOH. Searching for 'model liquidator' or similar provides essentially references to bankruptcy predicting model literature ${ }^{11}$ and to the UNCITRAL Model Law. These results do not help either. So what type of modelling would facilitate research relating to the IOH position? Any kind of analysis is based on (research) questions. In academic work, these questions should form a coherent and consistent framework and are to be formulated precisely. This framework defines the specific approach to the issues analysed at hand. Whether it is legislation, an academic legal study or a lecture, the set-up of each of those is governed by an implicit or explicit approach. Implicit approaches are, for example, found in civil law-based legal handbooks that often describe the law along the articles of legislation. This paper argues that an analysis of the law may be enriched by explicitly formulating research questions based on a coherent model.

According to the Oxford Dictionary, a model is a simplified description (...) of a system or process. ${ }^{12}$ On a scientific level, Ritchey (2012) shows that there exists no general theory of modelling. As one of the reasons, he states that '(m)aybe no stable theoretical framework can be created to treat these concepts in both a (logically) consistent and (epistemologically) complete manner (...). ${ }^{13}$ To him, concepts as

\footnotetext{
3. Leiden Law School is part of Universiteit Leiden, Leiden, The Netherlands.

4. To be found in footnotes 1 and 23.

5. This paper incorporates as well our methodological experiences in an INSOL Europe assignment to design 'Guidelines for out-of-court restructuring and turnaround professionals', which the first two authors conducted from November 2014 till October 2015. Although the text of this paper may show textual differences with expressions applied in the reports for INSOL Europe on the $I O H$ project, the ideas behind this paper and our reports are similar.

6. On 1 February 2016.

7. See, for example, André Valente and Foost Breuker, 1995, ON-LINE: An Architecture for Modelling Legal Information, 1995, Proceedings of the conference on Artificial intelligence and law.

8. See, for example, M. Bergara, B. Richman, P. T. Spiller, 2003, Modeling Supreme Court strategic decision making: The congressional constraint, - Wiley Online Library.

9. See, for example, T. Bhagya, S. Vasanthapriyan, $P$. Fayaweera Collaboration Modelling Framework for Courts
}

Hearing, Workflow Specification, Developing Country Studies Vol. 4, No. 13, 2014 - Special Issue, www. iiste.org, ISSN 2225-0565 (Online).

10. See, for example, H. Prakken, 1997, Logical Tools for Modelling Legal Argument. A Study of Defeasible Reasoning in Law, Kluwer Law and Philosophy Library Dordrecht; and G. Sartor, L. Branting, 2013, Fudicial applications of artificial intelligence, Kluwer.

11. See, for an overview: B. P. A. Santen, 2011, On the Role of Monitoring near Financial Distress - an Economic and Legal Analysis, doctorate thesis, Erasmus University Rotterdam, chapters 6-8, available on the Internet.

12. An abbreviation from Oxford Dictionary of English, 3rd edition: A simplified description, especially a mathematical one, of a system or process, to assist calculations and predictions.

13. T. Ritchey, 2012, Outline for a Morphology of Modelling Methods - Contribution to a General Theory of Modelling, Acta Morphologica Generalis AMG Vol. 1 No. 1 (2012) p. 3. ISSN 2001-2241. 
a scientific model and scientific modelling are unclear qualifications. ${ }^{14}$ They should, however, have two criteria in common. The two criteria are (i) a scientific model must contain two or more mental constructs that can serve as variables, that is, dimensions (such as age or gender) that can support a range of values or states (1, 2, 3, etc. and male, female, etc.); (ii) one must be able to establish relationships either between the variables as such or between the values of the value ranges within the variables. ${ }^{15}$ With these criteria in place, a model may in our view allow for the identification of the key issues of the researched area and for a subsequent out-of-the-box $360^{\circ}$ analysis. In order to design the methodology for the INSOL Europe studies, we used this as our starting point. We formulated through induction a framework that explicitly accounts for the questions to be answered in order to obtain a proper view on the position of the $\mathrm{IOH}$. In a second phase and by deduction from that framework based on other materials, a model emerged for the analysis of the position of the $\mathrm{IOH}$. In this paper, we set out how we modelled the INSOL Europe studies.

\section{The Modelling of the INSOL Europe Studies}

The LLS researchers started the project by conducting a thorough analysis of the important issues concerning an $\mathrm{IOH}$ raised in national and international legal sources. ${ }^{16}$ They planned to determine the subjects of the Principles and Best Practices to be formulated only after this analysis and after a discussion of the results with the Review and Advisory Group ('R\&A') to the project. The R\&A consisted of practitioners, judges and scholars from various countries and was established by INSOL Europe in order to keep the researchers on a track that would lead to applicable outcomes in practice. Fig. 1 summarises this methodology.

The question remained on which basis the 'analysis of issues', which is decisive for the outcome of the assignment, had to be conducted. The approach is twofold. Firstly, the researchers went through an inductive phase, in which they developed a framework for the analysis. Thereafter, and based on this framework as well as on the legal systems and other materials they studied, they deducted a model for the analysis.

\subsection{Phase 1: towards a framework by induction}

Based on a preliminary analysis of some randomly chosen international and national documents, our experience and some out-of-the-box brainstorm sessions, the researchers created a preliminary framework for the analysis of the position of IOHs alongside five questions as shown in Fig. 2.

$\overline{\text { 14. T. Ritchey, p. } 1 .}$

15. If these criteria are fulfilled, five properties will determine the model. These are specification (the variables contain (specified) or do not contain (unspecified) values or states), directionality (the connection between the variables is symmetrical or asymmetrical), quantification (the relationships between the variables are quantified or not), cyclic relationships (the model allows for loops in the connectivity (cyclic) or not (acyclic)) and the type of connectivity (mathematical/functional, probabilistic, quasi-causal and non-causal).

16. Reports I and II and Appendices A and B mentioned in footnote 23 contain a survey of the documents studied. 


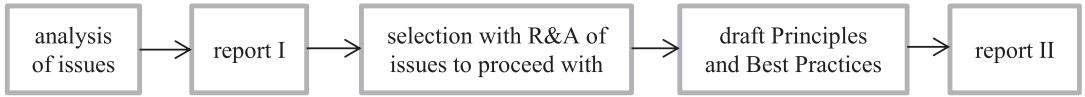

Figure 1. Methodology of Leiden Law School applied to the INSOL Europe projects. R\&A, Review and Advisory Group.
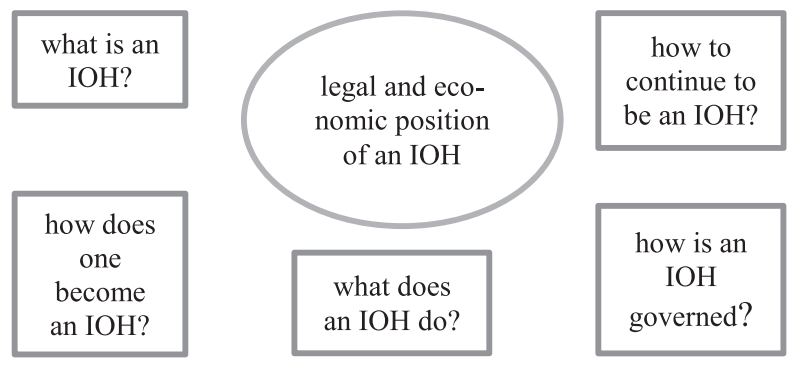

Figure 2. Preliminary framework for the analysis of Insolvency Office Holder (IOH) issues.

The questions formulated in Fig. 2 were thought to cover the IOH position because

1. The What is an IOH? question addresses what an IOH aims to achieve and how and by whom she or he is appointed.

2. The How does one become an IOH? question addresses whether there are any formal (legal or factual) requirements to become an $\mathrm{IOH}$, for example, on education, experience, absence of criminal record and membership.

3. The What does an $\mathrm{IOH}$ do? question addresses how an $\mathrm{IOH}$ is expected to operate during the assignment in terms of administration of the estate, managing expectations, clarification of the assignment, communication with creditors and other stakeholders and negotiation with third parties.

4. The How does one continue to be an IOH? question addresses whether there are requirements in the professional and ethical sphere concerning continuation of being an $\mathrm{IOH}$, for example, on continuous training, membership, insurance, experience, office organisation, compliance to certain rules, integrity, objectivity and independence, confidentiality and secrecy, avoiding conflicts of interests and absence of disciplinary measures.

5. The How is an IOH governed? question addresses whether and how an $\mathrm{IOH}$ is governed, for example, the legal and other requirements and the methods applied, for example, by inter-vision, through disciplinary boards of associations, by courts or by creditors.

These five questions form a framework that relates to all facets of an IOH's existence. They appear to have a logical order and to provide for a feedback mechanism, as shown in the final framework in Fig. 3 ('framework'). Before becoming an $\mathrm{IOH}$, one should know what the profession stands for. Once one knows what an $\mathrm{IOH}$ is and how to become one - these questions will be dealt with under one heading further on - the following relevant question is what kind of activities an $\mathrm{IOH}$ performs. While performing his or her activities an $\mathrm{IOH}$ should maintain and improve an adequate professional and ethical attitude for the sake of continuity. Continuous training and experience are essential. In addition, governance 


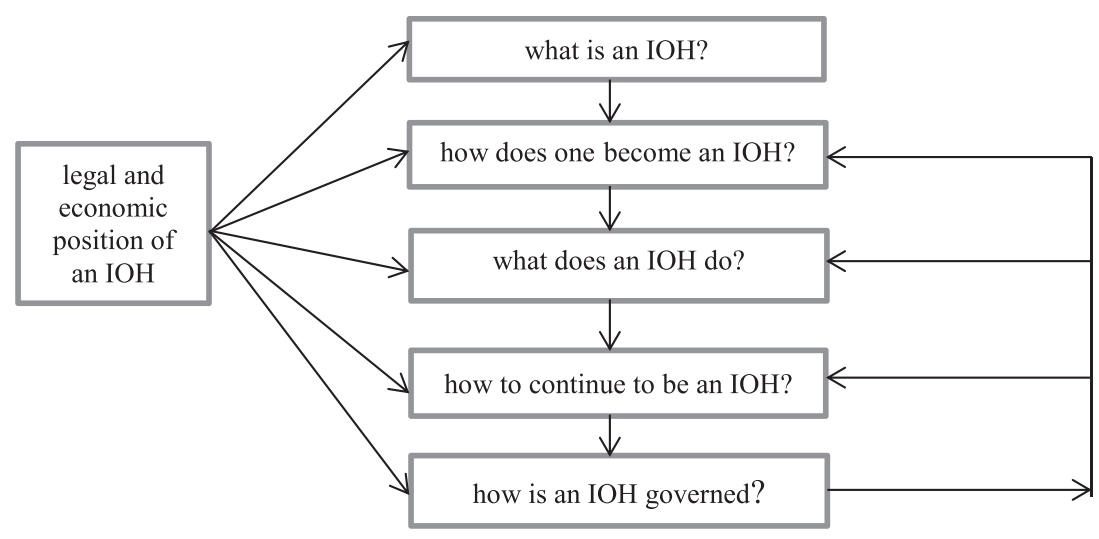

Figure 3. Framework for the analysis of the position of an Insolvency Office Holder (IOH).

mechanisms are vital to guarantee the quality of the $\mathrm{IOH}$ performance. If it is reported that the $\mathrm{IOH}$ profession in general $^{17}$ or a specific $\mathrm{IOH}$ is not performing well, there should be feedback. This should be directed either to improve the performance of an $\mathrm{IOH}$ in general by requiring, for example, higher barriers of admittance, better education or more regulation, or when it concerns a specific $\mathrm{IOH}$ to issue, for example, warnings or to possibly and ultimately expel the $\mathrm{IOH}$ from the profession.

\subsection{Phase 2: towards a model of analysis by deduction}

Based on the framework of Fig. 3, the research team started a preliminary analysis of international and national sets of rules. During the analysis, the framework gradually developed into a sufficiently detailed model with two new levels of expansion and refinement, as shown in Table 1. The framework presented in Fig. 3 was expanded with 15 Level II provisions ('Subcategories') and refined to 34 Level III provisions ('Topics') in order to enable categorisation into the framework of all relevant provisions. 'Subcategories' divide the categories into specific areas of attention. 'Topics' are the operational issues in those areas of attention. Table 1 presents this expanded and refined framework for the detailed analysis of rules for IOHs (further on referred to as the 'Model'). ${ }^{18}$ This Model incorporates the characteristics of a model required by Ritchey (2012) because it contains both a variety in dimensions, for example, 4 categories, 15 subcategories and 34 topics as well as relationships between the dimensions and their values (through the feedback system of the framework in Fig. 3). ${ }^{19}$

A few comments may serve to clarify this Model.

17. One of the governance mechanisms is publicity. Good examples of bad publicity on insolvency practice resulting in changes in the law are A. Gaudino, 1998, La Mafia des Tribunaux de Commerce, Albin Michel, p. 245, for France; and the Report of the Review Committee on Insolvency
Law and Practice, 1982, (also known as the Cork report), for the UK.

18. An earlier version of this model was designed by Matthijs Snïder LL.M. in his Master's thesis, supervised by Professors Bob Wessels and Iris Wuisman at LLS.

19. See chapter 1 of this paper. 
Table 1. Model for the analysis of a set of rules for Insolvency Office Holders (IOHs)

\begin{tabular}{|c|c|c|}
\hline Level I Categories & Level II Subcategories & Level III Topics \\
\hline \multirow{8}{*}{$\begin{array}{l}1.0 \text { How to become an } \\
\text { IOH (selection and } \\
\text { appointment) }\end{array}$} & 1.1 Licence and registration & 1.1.1 Requirements and contraindicators: \\
\hline & $\begin{array}{l}\text { how to become a } \\
\text { nominee IOH? }\end{array}$ & $\begin{array}{l}\text { education, professional qualification, } \\
\text { nationality }\end{array}$ \\
\hline & & $\begin{array}{l}\text { 1.1.2 Licencing procedures: internship, } \\
\text { exams and placement 'on the list' } \\
\text { for appointment }\end{array}$ \\
\hline & $\begin{array}{l}1.2 \text { Establishment of authority } \\
\text { how to become an IOH? }\end{array}$ & $\begin{array}{l}\text { 1.2.1 Basis of authority: court, creditor } \\
\text { or debtor }\end{array}$ \\
\hline & & $\begin{array}{l}\text { 1.2.2 Mandate: preservation, } \\
\text { reorganisation, continuation, liquidation } \\
\text { 1.2.3 (Inter)national recognition: } \mathrm{IOH} \\
\text { status abroad }\end{array}$ \\
\hline & $\begin{array}{l}1.3 \text { Corporate groups } \\
\text { one IOH, one estate? }\end{array}$ & $\begin{array}{l}\text { 1.3.1 Appointment of a single } I O H \text { : joint } \\
\text { administration }\end{array}$ \\
\hline & & $\begin{array}{l}\text { 1.3.2 Administration as one estate: } \\
\text { substantive consolidation }\end{array}$ \\
\hline & 2.1 Administration & 2.1.1 Managing the estate: safeguarding, \\
\hline \multirow{17}{*}{$\begin{array}{l}\text { 2.0 What does an } \\
\text { IOH do? } \\
\text { (Roles and } \\
\text { responsibilities) }\end{array}$} & manage the estate & $\begin{array}{l}\text { preservation of assets, administrative } \\
\text { organisation }\end{array}$ \\
\hline & & 2.1.2 Reversal of legal acts: possibility, \\
\hline & & conditions \\
\hline & & $\begin{array}{l}\text { 2.1.3 Agreements: continuation or } \\
\text { termination }\end{array}$ \\
\hline & & $\begin{array}{l}\text { 2.1.4 Creditor ranking: seniority, } \\
\text { different classes }\end{array}$ \\
\hline & & $\begin{array}{l}\text { 2.1.5 Liquidation: court involvement, } \\
\text { public/private }\end{array}$ \\
\hline & & $\begin{array}{l}\text { 2.1.6 Reorganisation: plans, finance, } \\
\text { lay-off }\end{array}$ \\
\hline & $\begin{array}{l}\text { 2.2 Liability and litigation } \\
\text { determine any debtors }\end{array}$ & $\begin{array}{l}\text { 2.2.1 Establishing liability: for example, } \\
\text { cause-analysis, wrongful and fraudulent } \\
\text { trading, of third parties, criminal } \\
\text { activities }\end{array}$ \\
\hline & & 2.2.2 Initiation of litigation: who does what? \\
\hline & $\begin{array}{l}2.3 \text { Communication inform } \\
\text { the stakeholders }\end{array}$ & $\begin{array}{l}\text { 2.3.1 Communication with creditors, courts } \\
\text { and other stakeholders: courts, creditors' } \\
\text { committee, confidentiality }\end{array}$ \\
\hline & & $\begin{array}{l}\text { 2.3.2 Communication protocol: mass } \\
\text { communication (creditors) }\end{array}$ \\
\hline & & $\begin{array}{l}\text { 2.3.3 Reporting standards: frequency and } \\
\text { placement }\end{array}$ \\
\hline & 2.4 Coordination and & 2.4.1 Coordination and cooperation among \\
\hline & cooperation & IOHs (in corporate groups) \\
\hline & & 2.4.2 Coordination and cooperation among \\
\hline & & foreign representatives (in cross-border insolvency) \\
\hline & & $\begin{array}{l}2.4 .3 \text { Coordination and cooperation with } \\
\text { foreign courts (in cross-border insolvency) }\end{array}$ \\
\hline \multirow{3}{*}{$\begin{array}{l}3.0 \text { How to continue to be an } \\
\text { IOH (Professional standards) }\end{array}$} & 3.1 Education & 3.1.1 Recurring training: once having \\
\hline & & passed licence requirements \\
\hline & 3.2 Professional skills & $\begin{array}{l}\text { 3.2.1 Experience: time spent, cases, } \\
\text { branches }\end{array}$ \\
\hline
\end{tabular}


Table 1. (Continued)

\begin{tabular}{|c|c|c|}
\hline Level I Categories & Level II Subcategories & Level III Topics \\
\hline \multirow{9}{*}{$\begin{array}{l}\text { 4.0 How is an IOH governed } \\
\text { (Insolvency governance) }\end{array}$} & & $\begin{array}{l}3.2 .2 \text { Other qualities: size office, regional } \\
\text { coverage, training }\end{array}$ \\
\hline & 3.3 Professional ethics & $\begin{array}{l}\text { 3.3.1 Ethical standards: adherence to } \\
\text { standards }\end{array}$ \\
\hline & 3.4 Insurance & $\begin{array}{l}\text { 3.4.1 Liability insurance: obligation, } \\
\text { amount, adaptation }\end{array}$ \\
\hline & 4.1 Accountability & $\begin{array}{l}\text { 4.1.1 Disclosures: focus on accountability } \\
\text { 4.1.2 Mandatory audit: any audit } \\
\text { mandatory? }\end{array}$ \\
\hline & & 4.1.3 Liability insurance: transparency \\
\hline & 4.2 Remuneration & $\begin{array}{l}\text { 4.2.1 Fees: protocol to determine fees } \\
\text { 4.2.2 Costs and expenses: protocol to } \\
\text { determine cost }\end{array}$ \\
\hline & 4.3 Supervision & $\begin{array}{l}\text { 4.3.1 Competent authority: competent } \\
\text { authority, power, suspension }\end{array}$ \\
\hline & 4.4 Disciplinary action & $\begin{array}{l}\text { 4.4.1 Investigation: investigation } \\
\text { possibilities }\end{array}$ \\
\hline & & $\begin{array}{l}\text { 4.4.2 Disciplinary proceedings: disciplinary } \\
\text { action to be taken by any third party }\end{array}$ \\
\hline
\end{tabular}

\subsubsection{Category 1.0}

Questions one and two concerning what an $\mathrm{IOH}$ is and how to become one are modelled in Category 1.0. This depicts the trajectory of the IOH selection and appointment. Requirements (Topic 1.1.1) generally regard education, professional status and nationality. Some systems apply regulations on office location and absence of contraindicators, for example, conviction of fraud and personal insolvency. When having fulfilled the requirements, the licencing procedures (Topic 1.1.2) come into play, which usually contain an internship varying from a few months up to 3 years and/or a number of cases dealt with; one or more exams either organised by the state or by a professional association; and finally the inscription on the list of eligibility, applied by the appointor. The IOH receives the mandate from an appointor, which depending on the system and the case may be a court, a creditor or the debtor. The law usually determines the mandate, for example, preservation, reorganisation, continuation and liquidation, which may be adjusted over time by court or creditor decision. The status and power of an IOH abroad is presently largely governed by the European Insolvency Regulation ${ }^{20}$ for the European Union member states, but national formal and material rules may still be relevant. The status of corporate groups is mentioned here because an IOH's power may be considerably enhanced when a court decides that the insolvency of a group of companies will be handled by one $\mathrm{IOH}$ ('joint administration') or even as one estate ('substantive consolidation'), which is possible in some European systems. These rules are set for the $\mathrm{IOH}$, she or he cannot

20. Council Regulation (EC) No 1346/2000.

Copyright (C) 2016 INSOL International and John Wiley \& Sons, LtdＩnt. Insolv. Rev., Vol. 25: 167-178 (2016) DOI: $10.1002 /$ iir 
deviate nor is there much freedom of policy. When the rules of this category 1.0 are clear, a reasonable and informed third party should understand (i) with which requirements a nominee $\mathrm{IOH}$ has to comply before she or he would even be considered for appointment; and (ii) what the basis of her or his authority is.

\subsubsection{Category 2.0}

Category 2.0 covers question three on the roles and responsibilities of the $\mathrm{IOH}$. First and foremost, this concerns the administration of the estate in all its different aspects, from record keeping and bookkeeping through managing, safeguarding and preservation of assets, to post-commencement financing and solving the reorganisation/liquidation question. The issues of the reversal of legal acts, the continuation of agreements and creditor ranking belong to this subcategory. The second responsibility of an $\mathrm{IOH}$ is to evaluate the conduct of the debtor or any third parties through, for example, cause-analysis and wrongful and fraudulent trading analysis and to establish liability, if any. Once established, the question arises who will initiate litigation. The third large role of the IOH is to communicate with creditors, courts and other stakeholders through calls, correspondence, reports and meetings, for example, with the creditors' committee. An issue in this respect is confidentiality. Other aspects are the existence of a communication protocol for mass communication with creditors and the reporting standards on frequency and placement of public reports. Finally, the various coordination and cooperation obligations of the $\mathrm{IOH}$ are taken into consideration, either among IOHs or with foreign courts. These are broadly the roles and responsibilities of an IOH once appointed, duly detailed in Level III Topics. An IOH has an area of freedom of policy or discretion here.

\subsubsection{Category 3.0}

Category 3.0 models the fourth question, which is on continuity of being an $\mathrm{IOH}$ professional. Does the system provide for recurring training once having passed the licencing procedures? What kind of professional skills remain required in terms of experience, for example, on time spent or number of cases handled; on specific branches; or on handling large or specific bankruptcies; and in terms of other qualities, for example, the size of the office, regional coverage and other professional skills or trainings. An element of the professional standards is the adherence to ethical standards, for example, impartiality, independence and objectivity. Lastly, we detect liability insurance as a professional standard. Are there any rules, are they mandatory or flexible, what guarantees are provided for the creditors? These standards concern the professional surroundings an IOH operates in. They enable a reasonable and informed third party to estimate and benchmark the level of personal professional capacities an $\mathrm{IOH}$ is deemed to have. What can be expected of the knowhow, experience, capabilities, ethical conduct and finally when things turn out wrong - of the financial 'cushion' of the IOH? 


\subsubsection{Category 4.0}

The last Category 4.0 - insolvency governance - is essentially about accountability to stakeholders in the insolvency proceedings. It covers accountability by disclosures in public reporting, by audit rules of the $\mathrm{IOH}$ administration and by transparence on the liability insurance of the $\mathrm{IOH}$, for example, the insured amount and the address of the insurer. Other aspects of insolvency governance are how remuneration and disbursements are determined, how an $\mathrm{IOH}$ is supervised and how disciplinary actions are initiated if any. These insolvency governance rules are the tailpiece of an insolvency system: monitoring of the IOH's work by means of various monitoring mechanisms, for example, the court, creditors or the creditors' committee, peers, the public, the auditor, the insurer and the debtor.

Together, these questions and categories form the Model. By going through the process of induction towards a Framework and subsequently towards the Model by deduction, the researcher is forced to thoroughly rethink the issues to be analysed. This extra step in the process lessens in our view the risks of academic or professional blind spots or cultural bias. The aim of this method is to enable a researcher to present a coherent, consistent and complete $360^{\circ}$ analysis of the position of an $\mathrm{IOH}$.

\section{Issues to be Dealt with in Principles and Best Practices}

The analysis of a country's system along the Model could result in a description of a maximum of 34 Topics for each set of rules. For the total analysis performed in the INSOL Europe studies on 11 countries and 13 sets of rules, this creates a total of maximum 816 observations. The data have been processed into a matrix with a short description if there was any information, columns containing information by Topic for each set of rules, and rows summarising the relevant information from all sets of rules for each of the 34 Topics. In this way, each column shows an analysis of each set of rules and each row of the matrix a topic analysis. An analysis of Topics was conducted from three viewpoints. Two are qualitative (targeted audience or regional focus and completeness), and one is quantitative (majority).

\subsection{Common ground on the basis of majority}

When counting, contrary to our expectations, only a few subcategories turned out to show an actual majority. If the notion of absolute majority were to be applied for the purpose of establishing common ground, there would hardly be any common ground provisions. Topics within subcategories such as 1.2 Establishment of authority and 2.1 Administration are one of the few areas that show a majority. However, a similar nature of provisions does not imply a similarity in content. Often, provisions are not compatible because each aims to achieve a different goal or a different level of detail. For instance, based on absolute majority, common ground could be established for the adoption of a provision with regard to 2.1.1 Managing the estate. The majority of sets of rules contain a provision in that area. However, the content 
of those provisions varies widely at some points. For example, whereas the World Bank Creditor Rights and Insolvency Standard consists of a number of provisions ranging from post-commencement finance to the disposal of assets, the Good Practice Standards of the Asian Development Bank call for 'swift action'. And although at a first glance in all countries upon opening the insolvency proceedings the right to manage the insolvency estate is transferred to the $\mathrm{IOH}$, this is not true anymore in various situations, especially after voluntary insolvency, for example, in the UK, Germany, Spain and France. This demonstrates that even in the same area of attention comparison is extremely difficult. An apparent majority will be affected by taking such differences in content into account. As a result, virtually no provision would qualify for common ground based on the absolute majority criterion.

\subsection{Targeted audience or regional focus}

One could also analyse the matrix from the viewpoint of the targeted audience of the set of rules, for example, insolvent companies, their directors, courts, creditors or IOHs. One could imagine that a similarly targeted audience, for example, creditors would deliver comparable rules. However, this assumption proved to be wrong. The analysis of the matrix based on targeted audience showed that no such relationship existed. Actually, some sets of rules with different targeted audiences had more in common than sets of rules with a similar targeted audience. An approach along regional origin or focus, for example, American or European, did not turn out to be fruitful as well.

\subsection{Completeness}

However, on one matter, we are confident: the analyses of 24 sets of rules have resulted in a model set out in Table 1 that almost certainly covers all relevant Topics of the IOH profession. All issues the researchers came across during their study were either already incorporated in the model or added after careful deliberation. The answers to the questions are of course related to the present era. New trends as pre-packs and out-of-court restructuring may bring forward new Topics. The authors feel however that the $\mathrm{IOH}$ analysis presented earlier will be a strong base of analysis for any IOH-related regulation.

Because no objective method appeared to exist to determine on which Categories, Subcategories or Topics a Principle or Best Practice was to be designed, at this point of our work clearly subjective choices came in. ${ }^{21}$ Which Topics would be facilitated by newly designed Principles and Best Practices? How would the R\&A react on these proposals? Would it be possible to phrase rules that really add something to laws or other rules already applicable? However, we feel that having to accept subjective choices enter our work after the Framework-

21. One could argue that adding new issues as explained in the previous paragraph depends on a relatively subjective appreciation as well.

Copyright (C) 2016 INSOL International and John Wiley \& Sons, Ltd Int. Insolv. Rev., Vol. 25: 167-178 (2016) DOI: 10.1002/iir 
based and Model-based analyses will probably lessen the chances to oversee, forget or bypass issues in the analysis and, by consequence, in one's assignment.

The researchers finally submitted the survey of Table 2 indicating the room for Principles and Best Practices.

According to Table 2, our research indicates room for 7 Principles and 22 Best Practices. The authors do not account for these choices in this paper because this would require an extensive analysis of the various subjective choices made in accordance with the R\&A, for example, concerning feasibility of certain draft rules in any European country's practice. ${ }^{22}$ However, up to this point, our line of reasoning has been objective to a large extent. This supposedly enables better subjective choices afterwards. The interested reader finds more on these choices in the reports prepared for INSOL Europe and available at the Turnaround Rescue and Insolvency Leiden ('TRI-Leiden') website. ${ }^{23}$

\section{Concluding Remarks}

This paper discusses the added value of modelling in an international comparative analysis of the position of the IOH. It presents a graphic Framework obtained by induction that gradually and deductively developed into a model in the actual analysis of 13 sets of international non-binding rules for IOHs and the insolvency law of 11 countries. This model proved to be a firm basis for the cross-border analysis of the $\mathrm{IOH}$ position.

Starting the analysis with induction towards a framework has the advantage that when it comes to formulating operational questions in the deductive phase, one is directed not only by what one sees, reads, hears and knows but also by what the conceptual phase has brought about in more abstract sessions of a brainstorming nature. This does not imply that errors, for example, missing issues, the overvaluation of personal experience, the misunderstanding of legal terms, the wrong interpretation of legal reasoning and legal practices, cannot occur. Analysing the law cannot be carried out mathematically. However, the approach described in this paper aims to reason as far as possible on an abstract level and to show the results in a graphic model. This method helps to lessen professional or academic blind spots or tunnel vision in the analysis and to easily oversee the issues at hand in a $360^{\circ}$ approach. More than a verbal description, such a graphic description allows for a quick glance and overview whether the model is relevant and complete. Moreover, a graphic illustration facilitates multidisciplinary research, because in other 'social' sciences, modelling is common. And although the verbal explanation of a model remains necessary, for those scientists, a model is easier to grasp than academic legal writing.

22. An assignment to design global Principles would therefore probably be impossible.

23. wrewe.tri-leiden.eu. I. S. Wuisman, 7. A. A. Adriaanse, B. P. A. Santen, European Principles and Best Practices for Insolvency Office Holders, Report I: an Analysis of Globally and Regionally Established Rules for Insolvency Office Holders (September 2013); J. A. A. Adriaanse, I. S. Wuisman,
B. P. A. Santen, Report II: A Comparative Analysis of Rules for Insolvency Office Holders in Eleven European Countries as a Means to Identify Room for Principles and Best Practices (April 2014); J. A. A. Adriaanse, I. S. Wuisman, B. P. A. Santen, Report III: the Statement of Principles and Best Practices for Insolvency Office Holders in Europe (October 2014). 
Table 2. The model and an indication for room for Principles and Best Practices for Insolvency Office Holders (IOHs)

\begin{tabular}{|c|c|c|c|c|}
\hline Level I Categories & Level II Subcategories & Level III Topics & $P$ & $B P$ \\
\hline \multirow[t]{3}{*}{$\begin{array}{l}\text { 1.0 How to become } \\
\text { an IOH (selection } \\
\text { and appointment) }\end{array}$} & $\begin{array}{l}1.1 \text { Licence and } \\
\text { registration }\end{array}$ & $\begin{array}{l}\text { 1.1.1 Requirements } \\
\text { and contraindicators } \\
\text { 1.1.2 Licencing procedures }\end{array}$ & $\mathrm{x}$ & $\mathrm{x}$ \\
\hline & $\begin{array}{l}\text { 1.2 Establishment } \\
\text { of authority }\end{array}$ & $\begin{array}{l}\text { 1.2.1 Basis of authority } \\
\text { 1.2.2 Mandate } \\
\text { 1.2.3 (Inter)national } \\
\text { recognition }\end{array}$ & & $\mathrm{x}$ \\
\hline & 1.3 Corporate groups & $\begin{array}{l}\text { 1.3.1 Appointment of a } \\
\text { single IOH } \\
\text { 1.3.2 Administration as } \\
\text { one estate }\end{array}$ & & $\mathrm{x}$ \\
\hline \multirow{10}{*}{$\begin{array}{l}\text { 2.0 What does an } \\
\text { IOH do? } \\
\text { (Roles and } \\
\text { responsibilities) }\end{array}$} & 2.1 Administration & 2.1.1 Managing the estate & $\mathrm{x}$ & $\mathrm{x}$ \\
\hline & & 2.1.2 Reversal of legal acts & & $\mathrm{x}$ \\
\hline & & 2.1.3 Agreements & & $\mathrm{x}$ \\
\hline & & $\begin{array}{l}\text { 2.1.4 Creditor ranking } \\
\text { 2.1.5 Liquidation } \\
\text { 2.1.6 Reorganisation }\end{array}$ & & \\
\hline & $\begin{array}{l}2.2 \text { Liability and } \\
\text { litigation }\end{array}$ & $\begin{array}{l}\text { 2.2.1 Establishing liability } \\
\text { 2.2.2 Initiation of litigation }\end{array}$ & & $\mathrm{x}$ \\
\hline & 2.3 Communication & $\begin{array}{l}2.3 .1 \text { Communication with } \\
\text { creditors, courts and other } \\
\text { stakeholders }\end{array}$ & $\mathrm{x}$ & $\mathrm{x}$ \\
\hline & & $\begin{array}{l}\text { 2.3.2 Communication } \\
\text { protocol }\end{array}$ & & $\mathrm{x}$ \\
\hline & & 2.3.3 Reporting standards & & $\mathrm{x}$ \\
\hline & $\begin{array}{l}2.4 \text { Coordination } \\
\text { and cooperation }\end{array}$ & $\begin{array}{l}2.4 .1 \text { Coordination and } \\
\text { cooperation among } \\
\text { IOHs (in corporate groups) }\end{array}$ & $\mathrm{x}$ & $\mathrm{x}$ \\
\hline & & $\begin{array}{l}2.4 .2 \text { Coordination and } \\
\text { cooperation among } \\
\text { foreign representatives } \\
\text { (in cross-border } \\
\text { insolvency) } \\
2.4 .3 \text { Coordination and } \\
\text { cooperation with foreign } \\
\text { courts (cross-border } \\
\text { insolvency) }\end{array}$ & & $\mathrm{x}$ \\
\hline \multirow{5}{*}{$\begin{array}{l}\text { 3.0 How to continue } \\
\text { to be an IOH } \\
\text { (Professional standards) }\end{array}$} & 3.1 Education & 3.1.1 Recurring training & $\mathrm{x}$ & $\mathrm{x}$ \\
\hline & 3.2 Professional skills & 3.2.1 Experience & & $\mathrm{x}$ \\
\hline & & 3.2.2 Other qualities & & $\mathrm{x}$ \\
\hline & 3.3 Professional ethics & 3.3.1 Ethical standards & $\mathrm{x}$ & $\mathrm{x}$ \\
\hline & 3.4 Insurance & 2.4.1 Liability insurance & & $\mathrm{x}$ \\
\hline \multirow{8}{*}{$\begin{array}{l}4.0 \text { How is an IOH } \\
\text { governed (Insolvency } \\
\text { governance) }\end{array}$} & 4.1 Accountability & 4.1.1 Disclosures & $\mathrm{x}$ & $\mathrm{x}$ \\
\hline & & 4.1.2 Mandatory audit & & $\mathrm{x}$ \\
\hline & & 4.1.3 Liability insurance & & $\mathrm{x}$ \\
\hline & 4.2 Remuneration & 4.2 .1 Fees & & $\mathrm{x}$ \\
\hline & & 4.2.2 Costs and expenses & & \\
\hline & 4.3 Supervision & 4.3.1 Competent authority & & \\
\hline & 4.4 Disciplinary & 4.4.1 Investigation & & \\
\hline & action & 4.4.2 Disciplinary proceedings & & $\mathrm{x}$ \\
\hline
\end{tabular}

